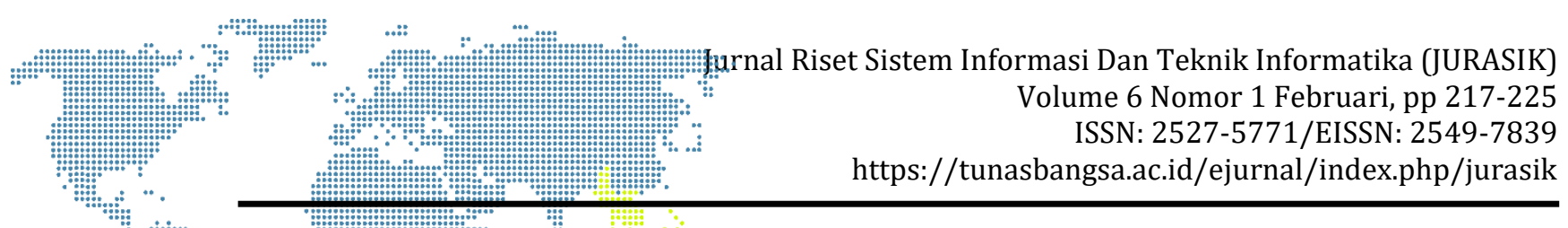

\title{
Analisa Kelayakan Penerima Program Keluarga Harapan (PKH) Menggunakan Algoritma C4.5
}

\author{
Muhammad Amirsyah Tanjung ${ }^{1}$, Poningsih ${ }^{2}$, Hendry Qurniawan ${ }^{3}$ \\ 1,3STIKOM Tunas Bangsa, Pematangsiantar, Sumatera Utara, Indonesia \\ ${ }^{2}$ AMIK Tunas Bangsa, Pematangsiantar, Sumatera Utara, Indonesia \\ Jln. Sudirman Blok A No. 1-3 Pematangsiantar, Sumatera Utara \\ 1amrsyh00@gmail.com, 2 poningsihamiktb@gmail.com
}

\begin{abstract}
In overcoming the problem of poverty, the Government implements the Family Hope Program (PKH) which is a program assistance that provides assistance (subsidies) in cash to poor households as long as they meet the requirements set out in the program. The purpose of this study is to determine whether the family is still eligible or not receive the Family Hope Program (PKH) assistance, where there are many other disadvantaged families who have not had the opportunity to receive this assistance program. Sources of data obtained from the Martoba Village Head Office. The method used in the study is a data mining technique with the C4.5 algorithm which is implemented with the RapidMiner application. The attributes used in determining the family's eligibility are still feasible or not receiving assistance from this assistance program, namely income, number of family dependents, vehicle ownership and residence status. The results of the classification algorithm C4.5 and testing with Rapid Miner software, it is found that the factor that most influences the eligibility of the Family Hope Program (PKH) recipients is the number of stages (C1) with an acquisition value of 0.51827179.
\end{abstract}

Keywords: C4.5 Algorithm, Data mining, PKH

\begin{abstract}
Abstrak
Dalam menanggulangi masalah kemiskinan, Pemerintah melaksanakan Program Keluarga Harapan (PKH) yang merupakan bantuan program yang memberikan bantuan (subsidi) tunai kepada rumah tangga miskin sepanjang mereka memenuhi persyaratan yang ditetapkan dalam program. Tujuan penelitian ini untuk menentukan apakah keluarga tersebut masih layak atau tidak menerima bantuan Program Keluarga Harapan (PKH) ini, dimana masih banyak keluarga tidak mampu lainnya yang belum berkesempatan menerima program bantuan ini. Sumber data yang diperoleh dari Kantor Lurah Martoba. Metode yang digunakan dalam penelitian adalah teknik data mining dengan algoritma C4.5 yang diimpelementasikan dengan aplikasi RapidMiner. Atribut yang digunakan dalam menentukan kelayakan keluarga tersebut masih layak atau tidak menerima bantuan program bantuan ini yaitu penghasilan, jumlah tanggungan keluarga, kepemilikan kendaraan dan status tempat tinggal. Hasil dari klasifikasi menggunakan algoritma C4.5 dan pengujian dengan software RapidMiner maka didapatkan faktor yang paling berpengaruh terhadap kelayakan penerima Program Keluarga Harapan (PKH) adalah jumlah penghasilan (C1) dengan nilai gain sebesar 0,51827179 .
\end{abstract}

Kata kunci: Algoritma C4.5, Data mining, $P K H$

\section{PENDAHULUAN}

Kemiskinan adalah kondisi ketidakmampuan seseorang dalam memenuhi kebutuhan sehari-hari. "Seseorang disebut miskin dapat dilihat dari pendapatannya, apabila pendapatannya rendah maka seseorang tersebut tidak dapat memenuhi kebutuhannya dan tidak dapat mensejahterakan dirinya" [1]. Dalam menanggulangi kemiskinan tersebut pemerintah melaksanakan Program Keluarga Harapan (PKH) yang merupakan program bantuan yang memberikan bantuan tunai kepada rumah tangga miskin sepanjang mereka memenuhi 


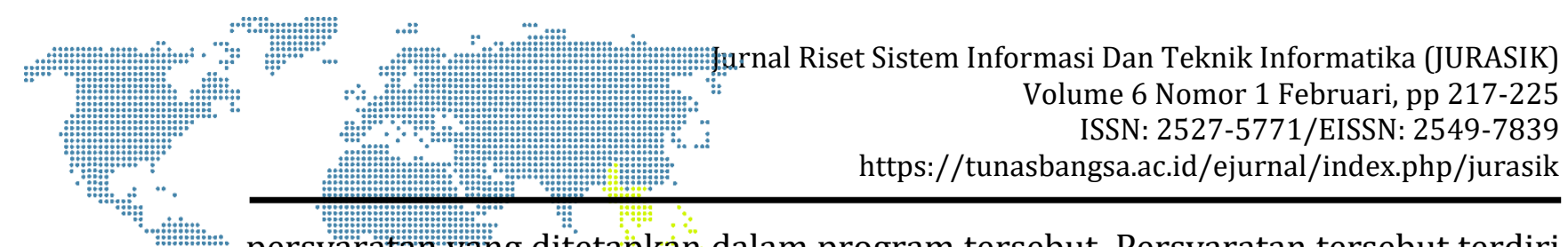

persyaratan yang ditetapkan dalam program tersebut. Persyaratan tersebut terdiri diari beberapa komponen yaitu ibu hamil, memiliki anak usia dini, SD, SMP, SMA,

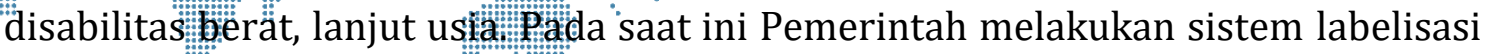
rumah pada setiap rumah yang menerima PKH. Sistem labelisasi rumah tersebut merupakan bentuk sosialisasi yang diupayakan Sumber Daya Manusia (SDM) PKH agar keluarga yang telah mampu mempunyai budaya malu. Namun dilapangan, banyak keluarga yang sudah mampu yang belum mengundurkan diri dari penerimaan bantuan program ini, sehingga tidak memberikan kesempatan kepada keluarga tidak mampu lainnya yang belum berkesempatan untuk mendapatkan bantuan program ini.

Untuk mengatasi permasalahan diatas dapat menggunakan klasifikasi dengan Algoritma C4.5. "Klasifikasi merupakan proses pencarian model yang membedakan kelas data agar model tersebut dapat digunakan untuk memprediksi kelas dari suatu objek yang belum diketahui kelasnya. Salah satu algoritma klasifikasi yang bisa digunakan adalah C4.5" [2]. Dengan menggunakan metode Algoritma C4.5 akan diklasifikasi data penerima PKH untuk memberikan masukan kepada pemerintah dalam menentukan apakah keluarga tersebut masih layak atau tidak menerima bantuan. Kajian penelitian terdahulu yaitu (Irmayansah 2018) yang berjudul "Penerapan Algoritma C4.5 Untuk Klasifikasi Penentuan Penerimaan Bantuan Langsung di Desa Ciomas". Penelitian ini mengklasifikasikan penduduk yang tidak mampu berdasarkan sensus ekonomi penduduk dengan 10 variabel yang digunakan yaitu atap rumah, jenis pekerjaan, jenis dinding rumah terluas, jenis lantai rumah terluas, sumber penerangan umum, sumber air minum, bahan bakar utama untuk memasak, fasilitas tempat buang air besar, status rumah, luas rumah. Pada penelitian tersebut perlu ditambahkannya variabel penghasilan terhadap penduduk tersebut dimana variabel ini cukup mempengaruhi penduduk tersebut untuk mendapatkan penerimaan bantuan.

Dengan Tujuan untuk menentukan apakah keluarga tersebut masih layak atau tidak menerima bantuan program ini, dimana masih banyak keluarga tidak mampu lainnya yang belum berkesempatan untuk mendapatkan program bantuan ini. Hasil dari penelitian ini diharapkan dapat memberikan informasi dan masukan kepada Pemerintah dalam menentukan apakah keluarga yang sudah menerima bantuan masih layak atau tidak menerima bantuan Program Keluarga Harapan (PKH) ini, sehingga memberikan kesempatan kepada keluarga yang tidak mampu lainnya untuk mendapatkan bantuan program ini.

\section{METODOLOGI PENELITIAN}

\subsection{Pengumpulan Data}

Penelitian ini dilakukan di Kelurahan Martoba yang terletak di Kecamatan Siantar Utara, Kota Pematangsiantar. Pengumpulan data yang penulis lakukan diperoleh melalui Kantor Lurah Martoba akan di olah sebanyak 163 keluarga yang menerima PKH. Penulis melakukan observasi kepada keluarga yang menerima PKH dengan jumlah 100 sampel data.

Atribut data yang digunakan terdiri dari : 


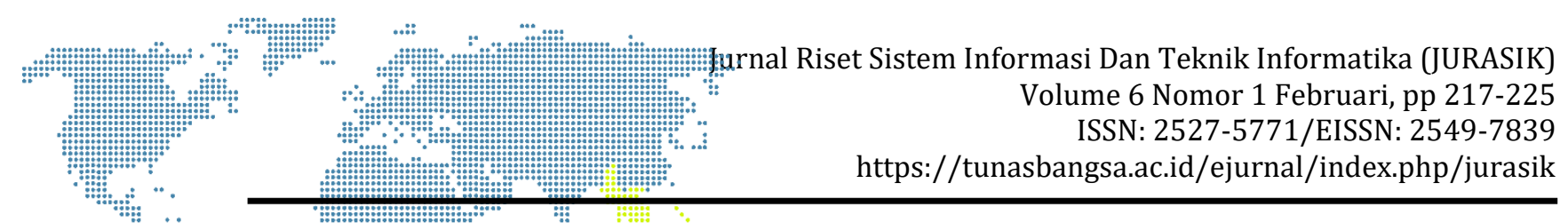
a) Junitalemenghasilan
b) Juniniale Tanggungan Keluärga
c) Kepemilikan Kendariasan
d) Status Tempat Tinggal.

Penjelasan atribut dapat dilihat pada tabel dibawah ini :

Tabel 1. Penjelasan Atribut

\begin{tabular}{|c|l|l|}
\hline No. & \multicolumn{1}{|c|}{ Atribut } & \multicolumn{1}{c|}{ Penjelasan } \\
\hline $\mathbf{1 .}$ & Jumlah Penghasilan & $\begin{array}{l}\text { Rendah (Penghasilan }<1 \text { jt perbulan), } \\
\text { Cukup (Penghasilan } \geq 1 \text { jt }-\leq 1,5 j t \text { perbulan), } \\
\text { Tinggi (Penghasilan }>1,5 j t \text { perbulan) }\end{array}$ \\
\hline $\mathbf{2 .}$ & $\begin{array}{l}\text { Jumlah Tanggungan } \\
\text { Keluarga }\end{array}$ & $\begin{array}{l}\text { 0 (Tidak mempunyai anak), 1 (Jumlah anak 1) 2 } \\
\text { (Jumlah anak 2), }>2 \text { (Jumlah anak }>2 \text { ) }\end{array}$ \\
\hline 3. & $\begin{array}{l}\text { Kepemilikan } \\
\text { Kendaraan }\end{array}$ & $\begin{array}{l}\text { Tidak Punya (Tidak mempunyai kendaraan), } \\
\text { Rendah (Sepeda), Cukup (1-2 Sepeda Motor), Tinggi } \\
\text { (>2 Sepeda Motor, (Mobil)) }\end{array}$ \\
\hline 4. & $\begin{array}{l}\text { Status Tempat } \\
\text { Tinggal }\end{array}$ & Numpang, Kontrak, Milik Sendiri \\
\hline
\end{tabular}

\subsection{Metode Penelitian}

\section{a) Data Mining}

Data Mining adalah proses mencari pola atau informasi menarik dalam data terpilih menggunakan teknik atau metode tertentu[3]. Data mining dapat diartikan juga sebagai pengesktrakan informasi baru dari data besar. Istilah data mining kadang disebut juga Knowledge Discovery in Database (KDD) [4].

\section{b) Algoritma C4.5}

Algoritma C4.5 merupakan pengembangan dari algoritma ID3 yang dicipt9akan oleh J. Rose Quinlan [3]. Algoritma C4.5 merup9akan salah satu metode klasifikasi yang menggunakan represe9ntasi struktur pohon (tree) dimana setiap node merepre9sentasikan atribut, cabangnya merepresentasikan nilai dari atrib9ut dan daun merepresentasikan kelas [7]. Menurut (Muhamad, Windarto \& Suhada 2019) secara umum untuk membangun pohon keputusan Algoritma C4.5 adalah sebagai berikut :

1) Pilih atribut sebagai akar

2) Buat cabang untuk masing-masing nilai

3) Bagi kasus dalam cabang

4) Ulangi proses untuk masing-masing cabang sampai semua kasus pada cabang memiliki kelas yang sama.

Untuk memilih atribut sebagai akar, didasarkan pada nilai gain tertinggi dari atribut-atribut yang ada. Untuk menghitung gain menggunakan rumus seperti berikut :

$$
\operatorname{Gain}(S, A)=\operatorname{Entropy}(S) \sum_{i=1}^{n} \frac{\left|S_{i}\right|}{|S|} * \operatorname{Entropy}(S i)
$$

Keterangan:

S : Himpunan kasus 


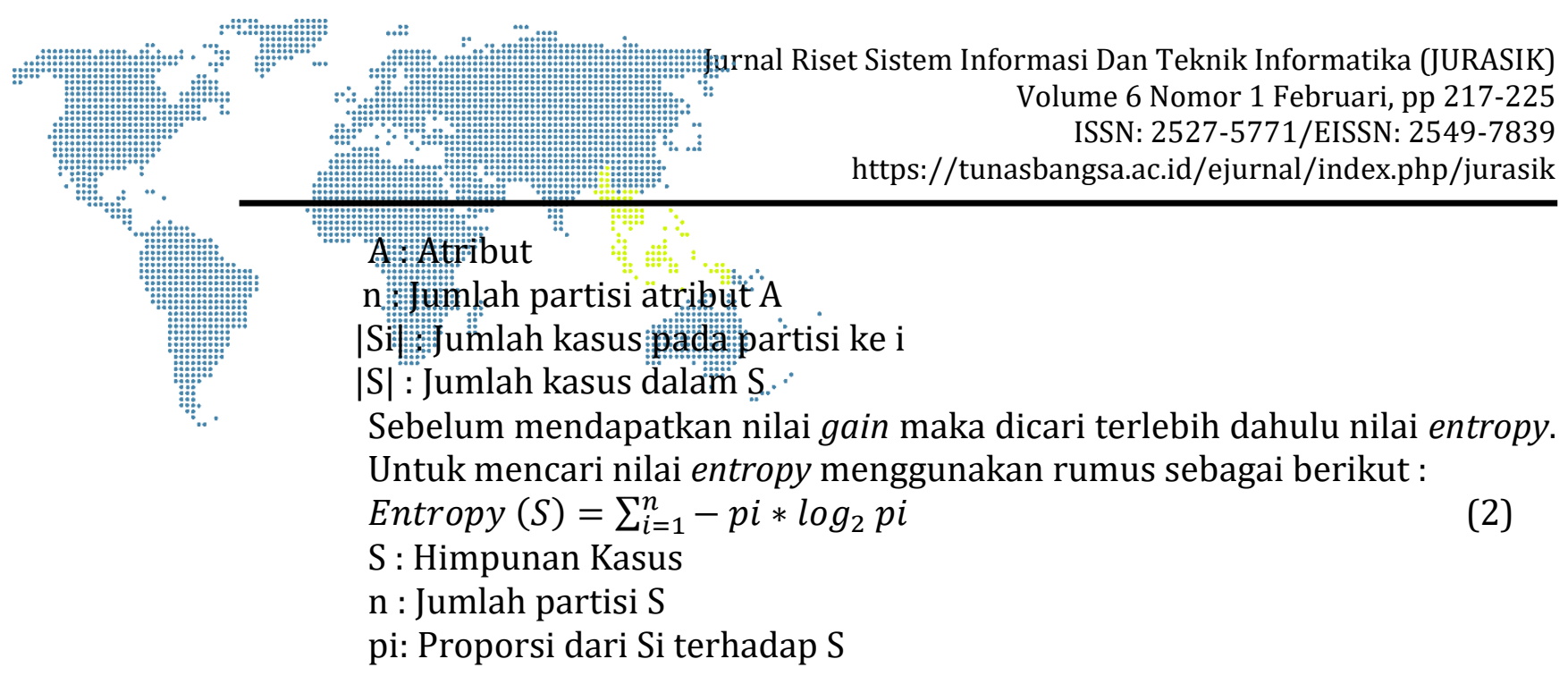

\section{HASIL DAN PEMBAHASAN}

\subsection{Perhitungan Menggunakan Metode K-means}

Perhitungan algoritma C4.5 dimulai dengan memilih atribut akar terlebih dahulu dengan mencari jumlah kasus keseluruhan, jumlah kasus keputusan layak dan jumlah kasus keputusan tidak layak. Menghitung entrophy dari semua kasus yang dibagi berdasarkan Jumlah Penghasilan (C1), Jumlah Tanggungan (C2), Kepemilikan Kendaraan (C3) dan Status Tempat Tinggal (C4). Setelah itu dilakukan perhitungan gain untuk masing - masing atribut. Hasil perhitungan ditunjukkan oleh tabel berikut ini.

Tabel 2. Perhitungan Node

\begin{tabular}{|c|c|c|c|c|c|}
\hline & Jumlah (s) & Layak & Tidak Layak & Entrophy & Gain \\
\hline Total & 100 & 69 & 31 & 0,8931735 & \\
\hline \multicolumn{5}{|c|}{ Jumlah Penghasilan } & 0,51827179 \\
\hline & Rendah & 40 & 40 & 0 & 0,0000000 \\
\hline & Cukup & 42 & 29 & 13 & 0,8926230 \\
\hline & Tinggi & 18 & 0 & 18 & 0,0000000 \\
\hline \multicolumn{5}{|c|}{ Jumlah Tanggungan } & 0,40370163 \\
\hline & 1 & 27 & 13 & 14 & 0,9990103 \\
\hline & 2 & 42 & 31 & 11 & 0,8296071 \\
\hline & $>2$ & 31 & 25 & 6 & 0,7088357 \\
\hline \multicolumn{5}{|c|}{ Kepmilikan Kendaraan } & 0,12702864 \\
\hline & Rendah & 0 & 0 & 0 & 0,0000000 \\
\hline & Cukup & 93 & 69 & 24 & 0,8238116 \\
\hline & Tinggi & 7 & 0 & 7 & 0,0000000 \\
\hline \multicolumn{5}{|c|}{ Status Tempat Tinggal } & 0,18777421 \\
\hline & Kontrak & 90 & 69 & 21 & 0,7837769 \\
\hline & Milik Sendiri & 10 & 0 & 10 & 0,0000000 \\
\hline
\end{tabular}

Dari hasil perhitungan pada tabel 3.1 diperoleh atribut yang menjadi node (akar) adalah C1 memiliki gain tertinggi yaitu 0,5568321, dimana terdiri dari 3 sub atribut yaitu Rendah (Berpenghasilan Rendah), Cukup (Berpenghasilan Cukup) dan Tinggi ( Berpenghasilan Tinggi). Berdasarkan nilai entrophy dari ketiga sub atribut diatas, sub atribut rendah sudah memiliki keputusan dan atribut tinggi sudah memperoleh keputusan, sedangkan sub atribut cukup belum memperoleh 


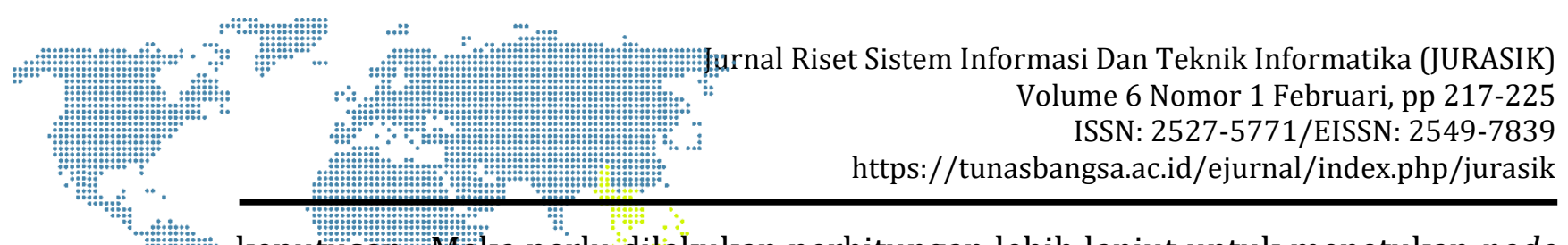

keputusan Naka perlu dilakukan perhitungan lebih lanjut untuk menetukan node akar selanim berikut:

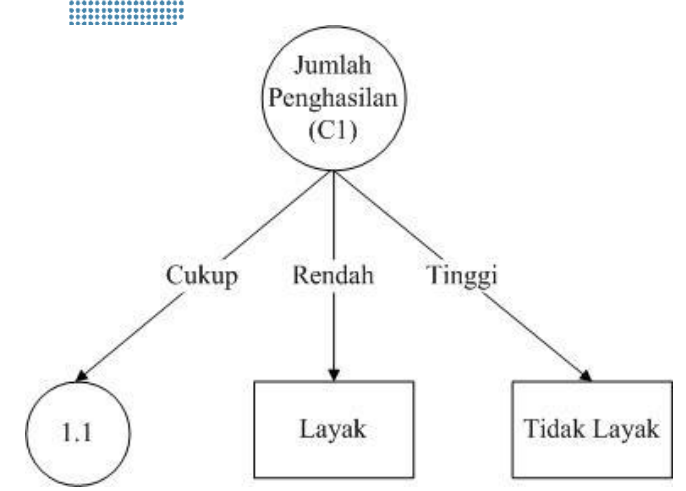

Gambar 1. Pohon Keputusan 1

Untuk hasil perhitungan selanjutnya algoritma C4.5 dapat ditunjukkan pada tabel berikut ini.

Tabel 3. Perhitungan Node 1.1

\begin{tabular}{|c|c|c|c|c|c|}
\hline \multirow[t]{2}{*}{ penghasilan = cukup } & Jumlah (s) & Layak & Tidak Layak & Entrophy & Gain \\
\hline & 42 & 29 & 13 & 0,8926230 & \\
\hline \multicolumn{5}{|l|}{ Jumlah Tanggungan } & 0,89262301 \\
\hline 1 & 11 & 0 & 11 & 0,0000000 & \\
\hline 2 & 13 & 11 & 2 & 0,6193822 & \\
\hline$>2$ & 18 & 18 & 0 & 0,0000000 & \\
\hline \multicolumn{5}{|l|}{ Kepmilikan Kendaraan } & 0,04122698 \\
\hline Rendah & 0 & 0 & 0 & 0,0000000 & \\
\hline Cukup & 41 & 29 & 12 & 0,8721618 & \\
\hline Tinggi & 1 & 0 & 1 & 0,0000000 & \\
\hline \multicolumn{5}{|l|}{ Status Tempat Tinggal } & 0,17808797 \\
\hline Kontrak & 38 & 29 & 9 & 0,7897493 & \\
\hline Milik Sendiri & 4 & 0 & 4 & 0,0000000 & \\
\hline
\end{tabular}

Dari hasil perhitungan diatas pada tabel 3.2, atribut yang menjadi Node cabang dari atribut C1 - Cukup adalah Jumlah Tanggungan (C2). Dimana atribut dari Jumlah Tanggungan (C2) yang terdiri dari 1, 2 dan $>2$. Dimana Jumlah Tanggungan (C2) 1 dan $>2$ sudah memperoleh keputusan Tidak Layak. Sedangkan untuk sub atribut Jumlah Tanggungan (C2) 2 belum memperoleh keputusan maka akan dilakukan perhitungan kembali. Maka dapat digambarkan pohon keputusan dari tabel diatas sebagai berikut : 


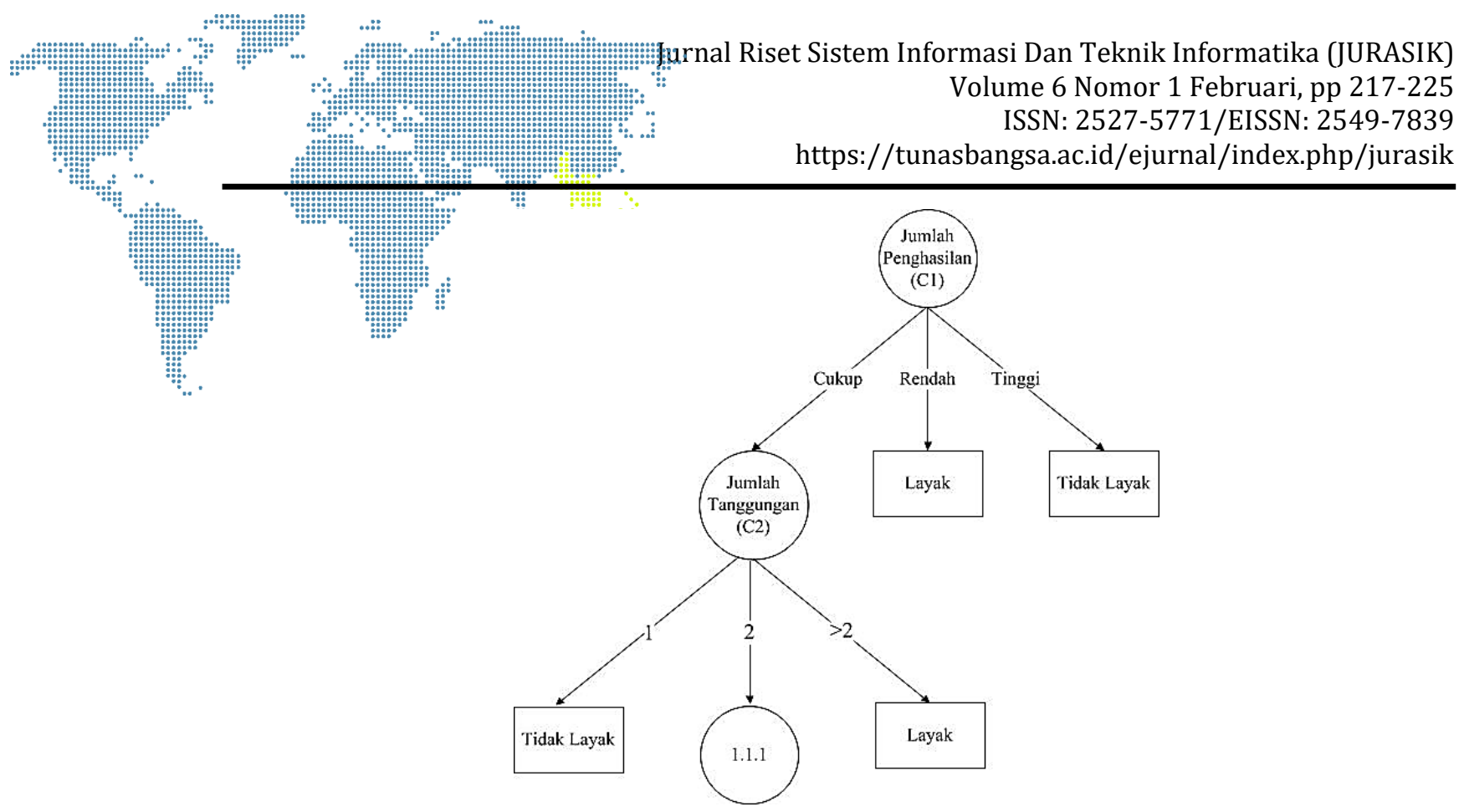

Gambar 2. Pohon Keputusan 2

Dalam mencari hasil perhitungan selanjutnya pada node akar C1-Cukup dan C2-2 dapat ditunjukkan pada tabel berikut ini.

Tabel 4. Perhitungan node 1.1.1

\begin{tabular}{|c|c|c|c|c|c|}
\hline \multirow[t]{2}{*}{$\begin{array}{c}\text { penghasilan }=\text { cukup dan } \\
\text { tanggungan } 2\end{array}$} & $\begin{array}{c}\text { Jumlah } \\
\text { (s) }\end{array}$ & Layak & $\begin{array}{l}\text { Tidak } \\
\text { Layak }\end{array}$ & Entrophy & Gain \\
\hline & 13 & 11 & 2 & 0,6193822 & \\
\hline \multicolumn{5}{|l|}{ Kepmilikan Kendaraan } & 0 \\
\hline Rendah & 0 & 0 & 0 & 0,0000000 & \\
\hline Cukup & 13 & 11 & 2 & 0,6193822 & \\
\hline Tinggi & 0 & 0 & 0 & 0,0000000 & \\
\hline \multicolumn{5}{|l|}{ Status Tempat Tinggal } & 0,23739741 \\
\hline Kontrak & 12 & 11 & 1 & 0,4138169 & \\
\hline Milik Sendiri & 1 & 0 & 1 & 0,0000000 & \\
\hline
\end{tabular}

Dari hasil perhitungan pada tabel 3.3, atribut yang menjadi node cabang dari C1Cukup dan C2-2 adalah C4. Dimana Status Tempa Tinggal (C4) Milik Sendiri keputusan Tidak Layak. Sedangkan untuk sub atribut Status Tempat Tinggal (C4) Kontrak belum memperoleh keputusan maka akan dilakukan perhitungan kembali. Maka dapat digambarkan pohon keputusan dari tabel diatas sebagai berikut : 


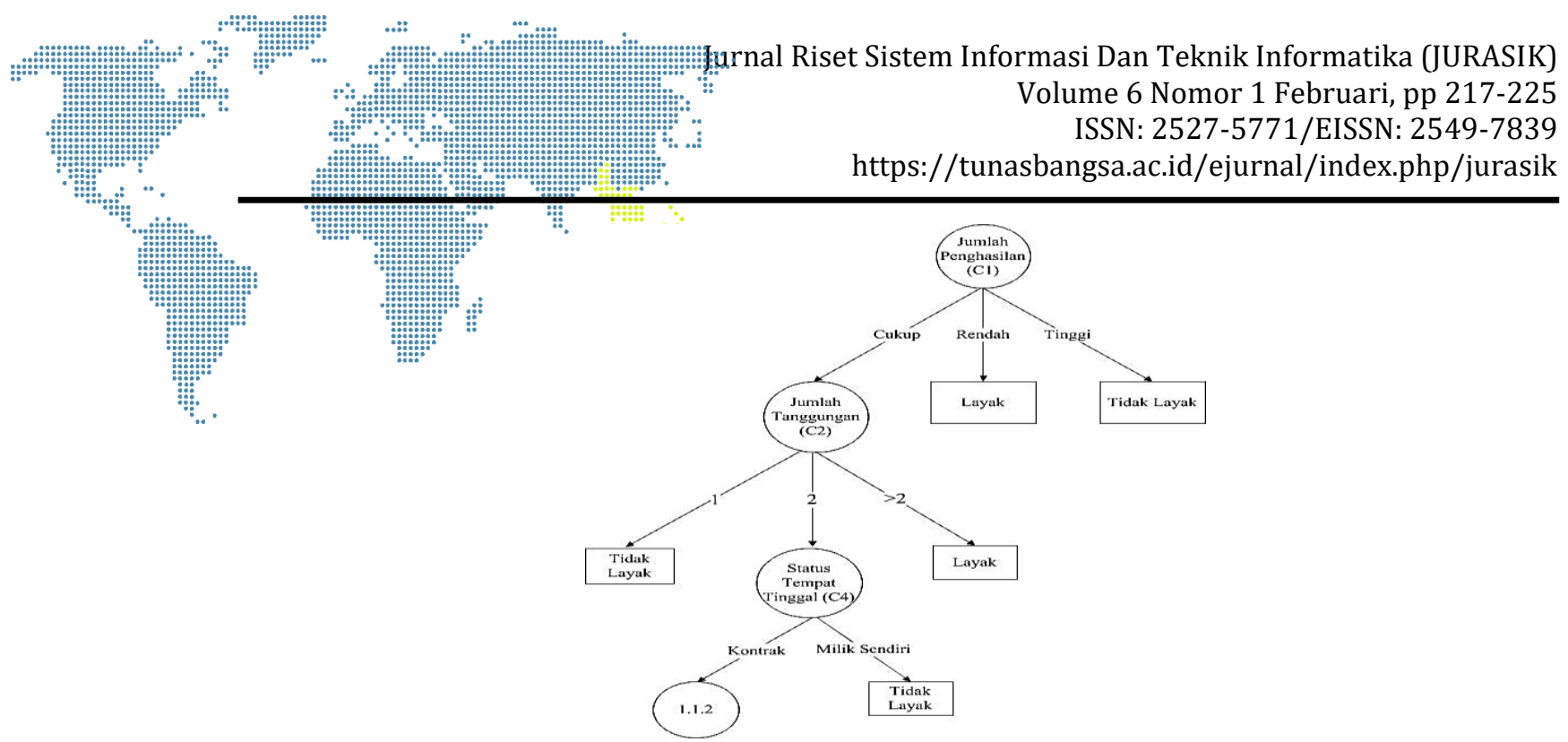

Gambar 3. Pohon Keputusan 3

Tabel 5. Perhitungan node 1.1 .2

\begin{tabular}{|c|c|c|c|c|c|}
\hline \multirow[t]{2}{*}{$\begin{array}{l}\text { Penghasilan = cukup dan } \\
\text { tanggungan } 2 \text { dan Kontrak }\end{array}$} & $\begin{array}{c}\text { Jumlah } \\
\text { (s) }\end{array}$ & Layak & $\begin{array}{c}\text { Tidak } \\
\text { Layak }\end{array}$ & Entrophy & Gain \\
\hline & 12 & 11 & 1 & $\begin{array}{c}0,413816 \\
9\end{array}$ & \\
\hline \multicolumn{5}{|l|}{ Kepmilikan Kendaraan } & 0 \\
\hline \begin{tabular}{l|r} 
& Rendah \\
& Ren
\end{tabular} & 0 & 0 & 0 & $\begin{array}{c}0,000000 \\
0\end{array}$ & \\
\hline Cukup & 12 & 11 & 1 & $\begin{array}{c}0,413816 \\
9\end{array}$ & \\
\hline Tinggi & 0 & 0 & 0 & $\begin{array}{c}0,000000 \\
0\end{array}$ & \\
\hline
\end{tabular}

Dari hasil perhitungan pada tabel 4.4, atribut yang menjadi node cabang dari C1Cukup, C2-2 dan C4-Kontrak adalah C3. Dimana semua atribut sudah memiliki keputusan dan perhitungan sudah selesai. Maka dapat digambarkan pohon keputusan dari tabel diatas sebagai berikut :

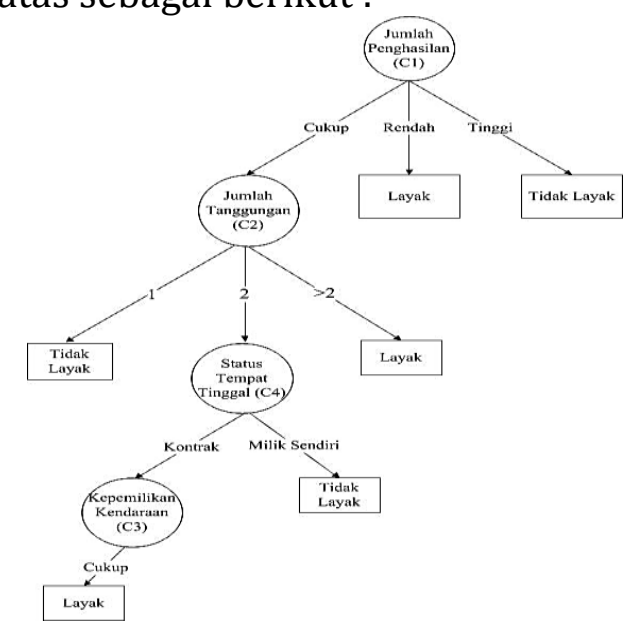

Gambar 4. Pohon Keputusan 4

Berikut ini rules yang dihasilkan dari pohon keputusan tersebut : 


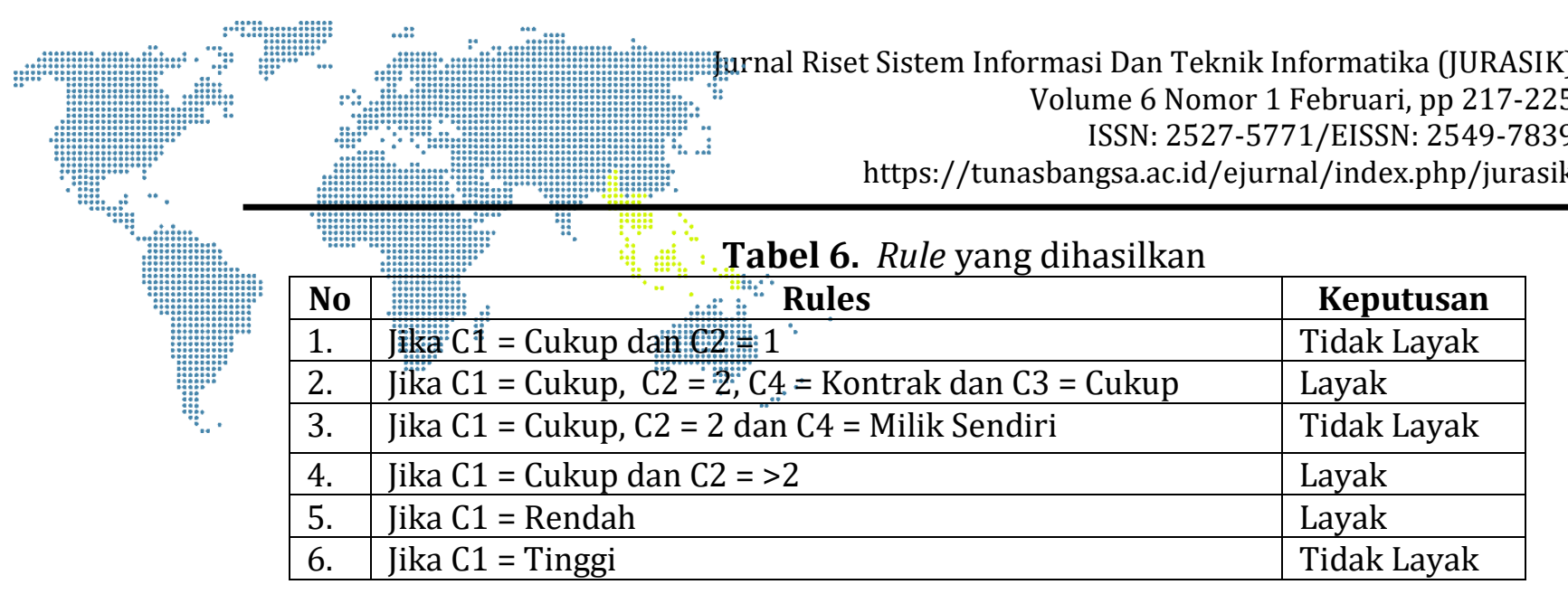

\subsection{Pengujian Data Menggunakan Rapidminer}

a) Setelah melakukan proses pengolahan data secara manual menggunakan metode algoritma c4.5 maka selanjutnya dilakukan proses pengujian data menggunakan tools rapidminer. Berikut adalah hasil pengujian data menggunakan tools rapidminer. Tampilan decision tree

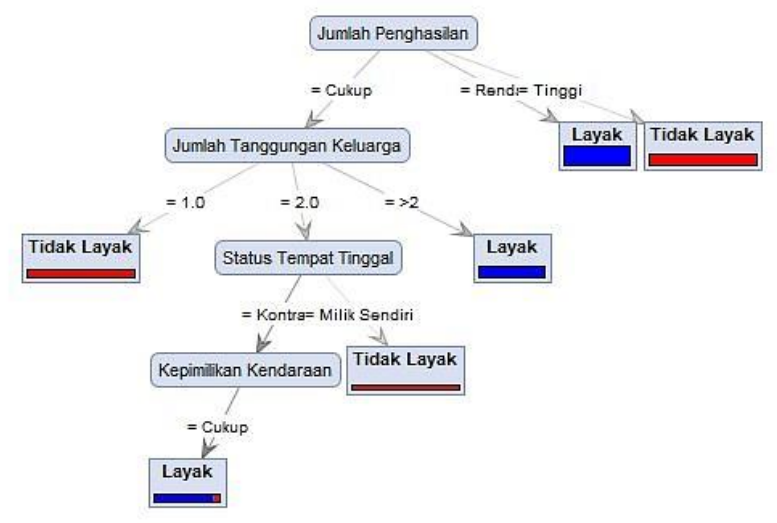

Gambar 5. Hasil decision tree

Setelah dilakukan perhitungan dan pengujian data pada masing-masing atribut dengan algoritma C4.5, maka akan didapatkan pola pohon keputusan akhir.

b) Tingkat Akurasi

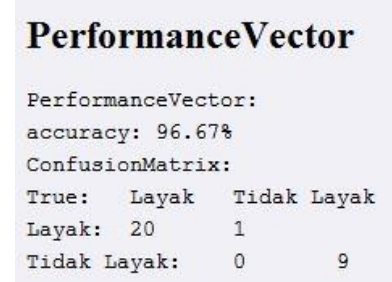

Gambar 6. Nilai Performance Vector Algoritma C4.5

Berdasarkan pengolahan data menggunakan software RapidMiner didapat nilai akurasi sistem sebesar 96,67\%, artinya bahwa rule yang dihasilkan tingkat kebenaran mendekati 100\%. Dimana model yang telah dibentuk diuji tingkat akurasinya dengan memasukan atau uji yang berasal dari data training dengan 


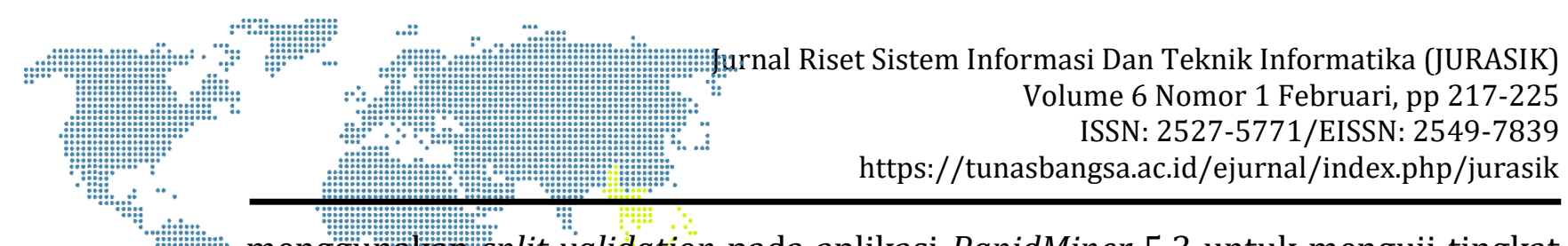

menggunakan split validation pada aplikasi RapidMiner 5.3 untuk menguji tingkat akurasi.

\section{SIMPULAN}

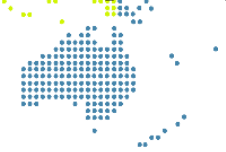

Berdasarkan seluruh hasil tahapan penelitian yang telah dilakukan pada Penerapan Algoritma C4.5 dalam mengklasifikasi masyarakat yang masih berhak atau tidak berhak menerima bantuan Program Keluarga Harapan (PKH) yang merupakan program bantuan yang dilaksanakan oleh Pemerintah dalam menanggulangi masalah kemiskinan dapat disimpulkan sebagai berikut :

a) Permasalahan menentukan masyarakat yang layak dan tidak layak dapat diselesaikan menggunakan teknik data mining, yaitu dengan Algoritma C4.5. menghasilkan 6 (Enam) rules dan tingkat akurasi yang dihasilkan oleh metode tersebut adalah 96,67\%.

b) Dengan adanya penerapan data mining algoritma C4.5 diharapkan mampu memberikan solusi kepada Pemerintah Kelurahan Martoba Kecamatan Siantar Utara Kota Pematangsiantar dalam menentukan masyarakat yang berhak dalam menerima bantuan Program Keluarga Harapan (PKH).

c) Dengan adanya penerapan data mining algoritma C4.5 diharapkan mampu mempermudah Pemerintah Kelurahan Martoba Kecamatan Siantar Utara Kota Pematangsiantar dalam memberikan bantuan Program Keluarga Harapan (PKH) ini kepada masyarakat yang benar-benar layak dan tidak salah sasaran.

\section{DAFTAR PUSTAKA}

[1] V. C. Pamungkas, L. Muflikhah, And R. C. Wihandika, "Klasifikasi Penerimaan Program Keluarga Harapan ( Pkh ) Menggunakan Metode Learning Vector Quantization ( Studi Kasus Desa Kedungjati )," Vol. 3, No. 3, Pp. 2659-2666, 2019.

[2] A. H. Nasrullah, "Penerapan Metode C4.5 Untuk Klasifikasi Mahasiswa Berpotensi Drop Out," Vol. 10, Pp. 244-250, 2018.

[3] Y. Mardi, "Data Mining: Klasifikasi Menggunakan Algoritma C4.5," J. Edik Inform., Vol. 2, No. 2, Pp. 213-219, 2019.

[4] S. Haryati, A. Sudarsono, And E. Suryana, "Implementasi Data Mining Untuk Memprediksi Masa Studi Mahasiswa Menggunakan Algoritma C4.5 (Studi Kasus: Universitas Dehasen Bengkulu)," J. Media Infotama, Vol. 11, No. 2, Pp. 130-138, 2015.

[5] E. P. Cynthia And E. Ismanto, "Metode Decision Tree Algoritma C.45 Dalam Mengklasifikasi Data Penjualan Bisnis Gerai Makanan Cepat Saji," Jurasik (Jurnal Ris. Sist. Inf. Dan Tek. Inform., Vol. 3, No. July, P. 1, 2018, Doi: 10.30645/Jurasik.V3i0.60.

[6] B. Hermanto And A. Sn, "Klasifikasi Nilai Kelayakan Calon Debitur Baru Menggunakan Decision Tree C4.5," Ijccs (Indonesian J. Comput. Cybern. Syst., Vol. 11, No. 1, P. 43, 2017, Doi: 10.22146/Ijccs.15946.

[7] M. A. Sembiring, "Penerapan Metode Decision Tree Algoritma C45 Untuk Memprediksi Hasil Belajar Mahasiswa Berdasarkan Riwayat Akademik," J. Teknol. Dan Sist. Inf., Vol. 3, No. 1, Pp. 60-65, 2016.

[8] S. Muhamad, Agus Perdana Windarto, "Penerapan Algoritme C4 . 5 Pada Klasifikasi," Komik (Konferensi Nas. Teknol. Inf. Dan Komputer), Vol. 3, Pp. 477-482, 2017, Doi: 10.30865/Komik.V3i1.1688. 